\title{
National Cancer Centre Singapore Consensus Guidelines for Hepatocellular Carcinoma
}

\author{
Pierce K. H. Chow ${ }^{a, b, h}$ Su Pin Choo ${ }^{c}$ David C. E. Ng ${ }^{d}$ \\ Richard H. G. Lo ${ }^{\text {e }}$ Michael L. C. Wang ${ }^{f}$ Han Chong Toh ${ }^{c}$ \\ David W. M. Tai ${ }^{c}$ Brian K. P. Goh ${ }^{b}$ Jen San Wong ${ }^{b}$ \\ Kiang Hiong Tay e Anthony S. W. Goh ${ }^{d}$ Sean X. Yan ${ }^{d}$ \\ Kelvin S. H. Loke d Sue Ping Thang ${ }^{d}$ Apoorva Gogna e \\ Chow Wei Too e Farah Gillian Irani e Sum Leong e \\ Kiat Hon Lim ${ }^{f}$ Choon Hua Thng ${ }^{g}$
}

aDivision of Surgical Oncology, National Cancer Centre Singapore, bepartment of Hepatopancreatobiliary/Transplantation Surgery, Singapore General Hospital, 'Division of Medical Oncology, National Cancer Centre Singapore, dDepartment of Nuclear Medicine \& PET, Singapore General Hospital, eDepartment of Diagnostic Radiology, Singapore General Hospital, fDepartment of Pathology, Singapore General Hospital, 9Division of Oncologic Radiology, National Cancer Centre Singapore, hOffice of Clinical Sciences, Duke-NUS Graduate Medical School, Singapore, Singapore

\section{Key Words}

Diagnosis · Hepatocellular carcinoma $\cdot$ Practice guidelines · Radiation therapy · Surgery

\begin{abstract}
Hepatocellular carcinoma ( $\mathrm{HCC}$ ) is the 6th most common cancer in the world, but the second most common cause of cancer death. There is no universally accepted consensus practice guidelines for HCC owing to rapid developments in new treatment modalities, the heterogeneous epidemiology and clinical presentation of HCC worldwide. However, a number of regional and national guidelines currently exist which reflect practice relevant to the epidemiology and collective experience of the consensus group. In 2014, clinicians at the multidisciplinary Comprehensive Liver Cancer Clinic (CLCC) at the National Cancer Centre Singapore (NCCS) reviewed the latest published scientific data and existing international and regional practice guidelines, such as those of the National Comprehensive Cancer Network, American Association for the Study of Liver Diseases and the Asian Pacific Association for the Study of the Liver, and modified them to reflect local practice. These would serve as a template by
\end{abstract}

Pierce K. H. Chow, MBBS, PhD

Division of Surgical Oncology, National Cancer Centre Singapore 11 Hospital Drive, 169610 Singapore (Singapore)

Tel. +65 6326 6091, E-Mail pierce.chow.k.h@singhealth.com.sg 
which treatment outcomes can be collated and benchmarked against international data. The NCCS Consensus Guidelines for HCC have been successfully implemented in the CLCC since their publication online on $26^{\text {th }}$ September 2014, and the guidelines allow outcomes of treatment to be compared to international data. These guidelines will be reviewed periodically to incorporate new data.

Copyright $@ 2016$ S. Karger AG, Basel

\section{Introductions}

Hepatocellular Carcinoma (HCC) is the 6th most common cancer in the world, but the second most common cause of cancer death [1]. In Singapore, from 2009 to 2013, it ranked as the third and fourth most common cause of cancer death amongst males and females, respectively [2].

There has been no set of universally accepted consensus practice guidelines for HCC treatment owing to rapid developments in new modalities of treatment [3] and the heterogeneous epidemiology and clinical presentation of HCC worldwide [4-6]. A number of regional and national guidelines currently exist, such as those from the American Association for the Study of Liver Disease (AASLD) [7], the European Association for the Study of the Liver [8], the Asian Pacific Association for the Study of the Liver (APASL) [9], the Japan Society of Hepatology [10], the Korean Liver Cancer Study Group [11], Hong Kong [12], and the National Comprehensive Cancer Network (NCCN) in the United States [13]. While these are evidence based, they reflect practice relevant to the epidemiology and collective experience of the consensus groups.

Clinicians at the multidisciplinary Comprehensive Liver Cancer Clinic (CLCC) at the National Cancer Centre Singapore (NCCS) met to establish consensus practice guidelines for HCC for the institution in October 2014. This multidisciplinary group reviewed the latest available scientific evidence and developed a set of practice guidelines which would be reviewed periodically to incorporate new data. The guidelines would serve as a template by which treatment outcomes can be collated and benchmarked against international data.

\section{Material and Methods}

A multidisciplinary group of clinicians from the NCCS's CLCC with prior experience in the joint management of HCC within the clinic convened two meetings in September and October 2014. These clinicians sought to formalize existing practice within the CLCC into a set of practice guidelines. Preliminary discussions were carried out online prior to the meetings. A management flowchart was drafted by several members, before being modified and elaborated on upon circulation to the rest of the team online. Subsequently, the two meetings served to facilitate verbal discussion and agreement. Consensus on all recommendations was reached by the second meeting, and the finalized flowchart was published thereafter on the NCCS website on $26^{\text {th }}$ September 2014 [14].

Amongst the clinicians were surgical oncologists and transplant surgeons $(n=3)$, medical oncologists $(n=3)$, a radiation oncologist $(n=1)$, nuclear medicine specialists $(n=5)$, interventional radiologists $(n=5)$, an oncology radiologist $(n=1)$, and a pathologist $(n=1)$. These specialists are leading clinicians involved in the development and implementation of diagnosis and treatment of a wide range of liver cancers.

The management flowchart was developed after reviewing the latest published scientific data and existing international and regional practice guidelines such as those of the NCCN, AASLD and the APASL, and modified to incorporate the latest scientific data and to reflect local practice.

Recommendations within the management flowchart are evaluated as per the Oxford criteria [15]. The levels of evidence are set out in parentheses where applicable. 


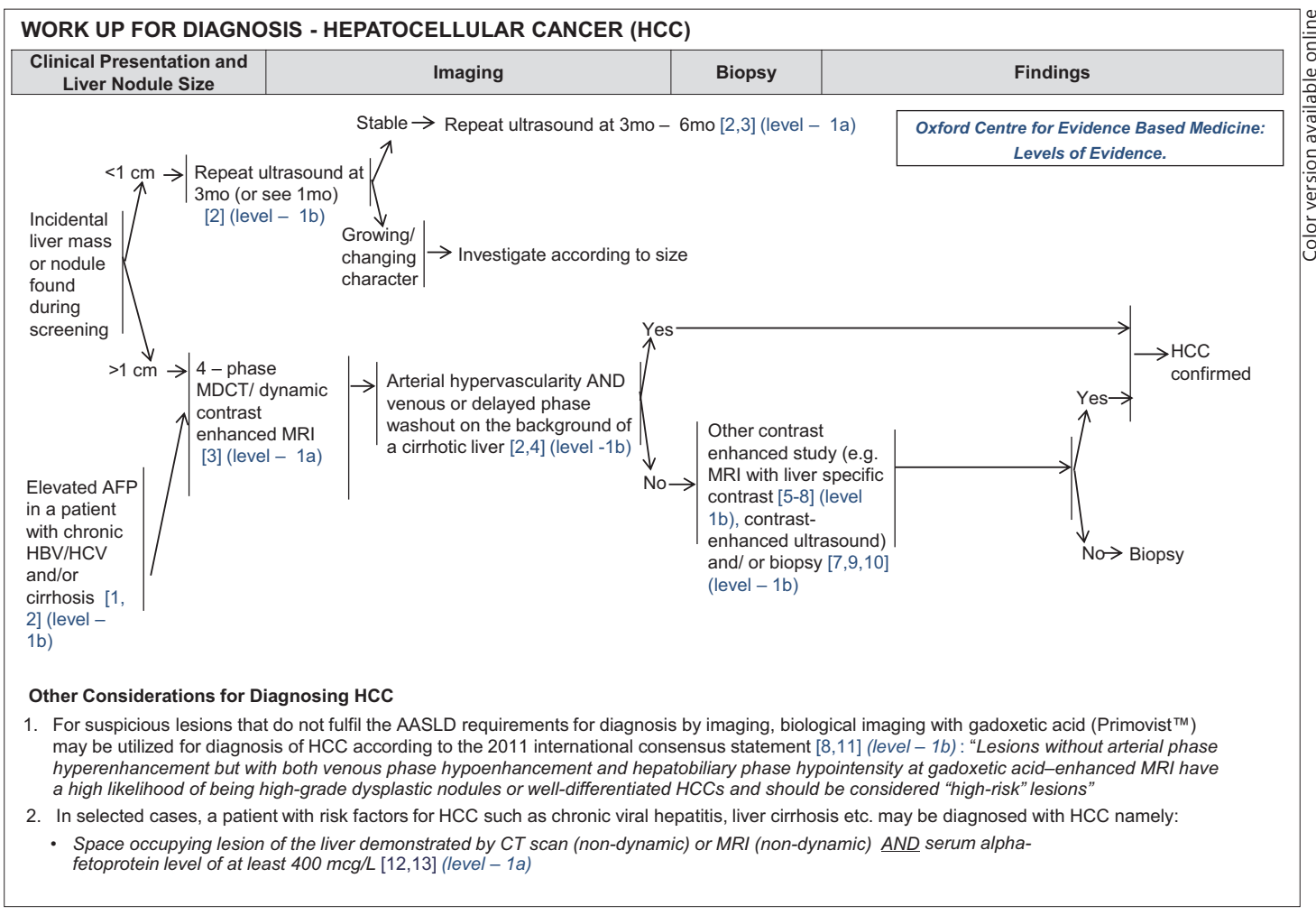

Fig. 1. NCCS Consensus Guidelines for HCC: Diagnosis. Recommendations within the flowchart were evaluated as per the Oxford Centre for Evidence Based Medicine: Levels of Evidence.

\section{Consensus Recommendations}

\section{A. Diagnosis}

The diagnosis of HCC is achieved by fulfilling the criteria of the AASLD Guidelines 2011; namely, lesions must be nodules larger than $1 \mathrm{~cm}$ in diameter with imaging appearances typical of HCC (i.e. hypervascular in the arterial phase with hypodensity in the portal venous or delayed phase) on a 4-phase (unenhanced, arterial, portal venous and delayed phases) multidetector computed tomography (MDCT) scan, or a 4-phase dynamic contrast enhanced magnetic resonance imaging (MRI) in a cirrhotic liver [7] (Level 1a Diagnosis/Therapy) (fig. 1).

For suspicious lesions that do not fulfill the AASLD requirements for diagnosis by imaging, biological imaging with gadoxetic acid (Primovist ${ }^{\mathrm{TM}}$ ) may be utilized for the diagnosis of HCC [16, 17] (Level 1b Diagnosis) (fig. 1). Lesions without arterial phase hyperenhancement, but with both venous phase hypoenhancement and hepatobiliary phase hypointensity by gadoxetic acid-enhanced MRI have a high likelihood of being high grade dysplastic nodules or well-differentiated HCCs, and should be considered "high-risk" lesions. Contrast enhanced ultrasound can also be considered, with or without biopsy [18-20] (Level 1b) (fig. 1).

An alternative diagnostic criterion can be met in patients with risk factors for HCC such as chronic viral hepatitis, liver cirrhosis, etc., if space occupying lesions of the liver demonstrated by CT scan (non-dynamic) or MRI (non-dynamic) are present, together with either a) serum alpha-feto protein (AFP) level of at least $400 \mathrm{mcg} / \mathrm{L}$ (Level 1a Diagnosis) (fig. 1) or b) dense homogenous lipiodol retention shown after hepatic lipiodol angiography with follow-up postlipiodol CT scan [21,22]. 


\begin{tabular}{|c|c|c|}
\hline \multicolumn{3}{|c|}{ TREATMENT STAGING } \\
\hline $\begin{array}{c}\text { Clinical } \\
\text { Presentation }\end{array}$ & Work Up & Treatment Staging \\
\hline HCC confirmed $\rightarrow$ & $\begin{array}{l}\text { Work Up } \\
\text { Multidisciplinary evaluation (assess liver reserve and } \\
\text { comorbidity) and staging: } \\
\text { - Hepatitis panel } \\
\text { - Renal panel } \\
\text { - Liver Function Test } \\
\text { - PT or INR } \\
\text { - FBC, platelets } \\
\text { - AFP } \\
\text { - Chest CT } \\
\text { - ICG retention test } \\
\text { if resection is considered }[14](\text { level }-1 b)\end{array}$ & 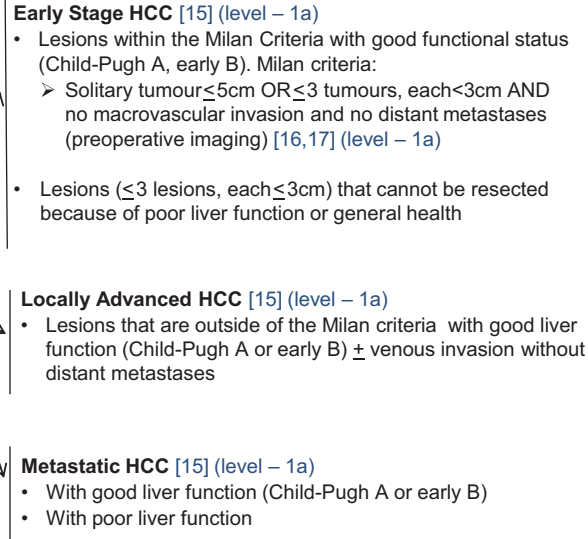 \\
\hline
\end{tabular}

Fig. 2. NCCS Consensus Guidelines for HCC: Treatment Staging. FBC=full blood count.

Suspicious lesions can still be diagnosed by biopsy after all of the above have been considered.

\section{B. Workup and Treatment Staging}

Once a patient has been diagnosed with HCC, two factors influence the workup, treatment staging and treatment options, namely 1) tumour burden and 2) liver function and general health of the patient.

Workup for patients diagnosed with HCC requires an evaluation based on: (a) hepatitis panel for detection of hepatitis B virus (HBV) and/or hepatitis C virus (HCV) infection; (b) renal panel (measuring blood urea nitrogen and creatinine); (c) liver function tests (measuring serum levels of bilirubin, aspartate transaminase, alanine transaminase, and alkaline phosphatase; measuring prothrombin time (PT) expressed as the international normalized ratio (INR), albumin and platelet count); (d) complete blood count; (e) measurement of serum AFP; (f) chest CT scan for assessing the presence of any comorbidity or metastatic disease in the lung ( $\mathrm{g}$ ) indocyanine green (ICG) retention test performed to assess liver function if resection is being considered for the patient [23, 24] (Level 1b Prognosis) (fig. 2), as may be appropriate.

Patients are then stratified accordingly into three stages on the basis of tumour burden [25]: 1) early stage HCC; 2) locally advanced HCC; 3) metastatic HCC. Within each stage, the patients are further assessed according to liver function.

Patients with early stage HCC [25] (Level 1a Therapy) (fig. 2) are defined by the Milan criteria i.e. solitary tumours $\leq 5 \mathrm{~cm}$ in diameter or multiple tumours numbering $\leq 3$, each $\leq 3 \mathrm{~cm}$ in diameter, and there must be no macrovascular invasion and no distant metastases shown during preoperative imaging [26, 27] (Level 1a Therapy) (fig. 2). A meta-analysis that was peer-reviewed and published by our institution has established that resection within the Milan criteria in patients with adequate liver function conferred a 5-year overall survival (OS) in excess of $60 \%$ and is potentially curative [27]. Similarly, outcomes of transplantation of HCC within the Milan criteria described in two publications based on the large transplant databases of the North American continent [28] and Europe [29] have shown 5-year OS also in excess of $60 \%$ and consistent with that of resection within the Milan criteria in 
patients with good liver function [29]. While a meta-analysis of five randomized-controlled trials (RCT) has shown that radiofrequency ablation (RFA) of HCC within the Milan criteria is inferior to that of surgical resection, 5-year OS of around 50\% was still achieved [30].

Locally advanced HCC [25] (Level 1a Therapy) (fig. 2) are tumours outside of the Milan criteria without any distant metastases, with or without vascular invasion. In patients with adequate liver function, such lesions are usually treated with locoregional therapy with median OS of 1-2 years [31-33]. Specifically selective internal radiation has conferred a median OS of up to 1-year in patients with locally advanced HCC with vascular invasion [31, 32, 34].

In patient with metastatic HCC [25] (Level 1a Therapy) (fig. 2) RCTs have established that treatment with the systemic therapy sorafenib, confers median OS of 6.5 [35] months and 10.7 months [36] in Asian and Western patients with adequate liver function, respectively.

\section{Treatment}

Once patients are staged into their respective tumour burdens of early HCC, locally advanced HCC and metastatic HCC, they are next evaluated on the basis of their underlying liver function. They are presented for discussion by a multidisciplinary team, who will select the appropriate modality of treatment by way of consensus. The reason(s) for any management decision reached by the team is subsequently documented.

Treatment should be individualized to each patient based on their unique characteristics, with tumour burden and liver function directing the treatment options available to the patient.

\section{Early Stage HCC Patients}

Patients with early stage HCC are first evaluated on the basis of fitness for surgical resection.

Patients with resectable disease have good liver function (Child-Pugh A or early B, good ICG retention at 15 mins), adequate future liver remnant and good general health [27, 28, 37-39] (Level 1a Therapy, Level 2b Prognosis, Level 1b Economic and Decision Analyses) (fig. 3). Liver transplantation can be a consideration in selected cases of early HCC with good liver function after multidisciplinary assessment, for example when future liver remnant is marginally adequate or where vascular margins are close.

Patients with unresectable disease involve those who have lesions that cannot be resected despite fulfilling the Milan Criteria because of poor liver function or general health $[23,24]$ (Level 1b Prognosis) (fig. 3), and/or an inadequate future live remnant (Level 2b Therapy) (fig. 3). These include patients with significant portal hypertension, varices, splenomegaly, severe ascites or thrombocytopenia and poor liver function assessed by the ICG retention tests [23, 24] (Level 1b Prognosis) (fig. 3). Patients with unresectable early stage HCC may be treated by RFA ( $\leq 3$ lesions, each $\leq 3 \mathrm{~cm}$ in diameter) [40] (Level 1a Therapy) (fig. 3 ) or transplantation [26] (Level 2b Therapy) (fig. 3), both of which are potentially curative modalities; external beam radiation therapy (EBRT) is an alternative when the patient is neither suitable for RFA or transplantation [41-43] (Level 1b Therapy) (fig. 3). Locoregional therapy such as transarterial chemoembolization (TACE) or selective internal radiation therapy (SIRT) can be considered in selected cases.

After treatment, imaging and monitoring of AFP should be carried out on follow-up. Imaging should be performed every 3-6 months for two years, then for every six months subsequently [7, 44] (Level 1a Diagnosis and Therapy) (fig. 3); in the presence of microvascular invasion, imaging should be performed every three months for two years, and should include the chest [37] (Level 2b Prognosis) (fig. 3). AFP should also be monitored every 3-6 months for two years, then for every six months subsequently.

Upon a relapse, patients should go thorough repeated workup and treatment staging. 


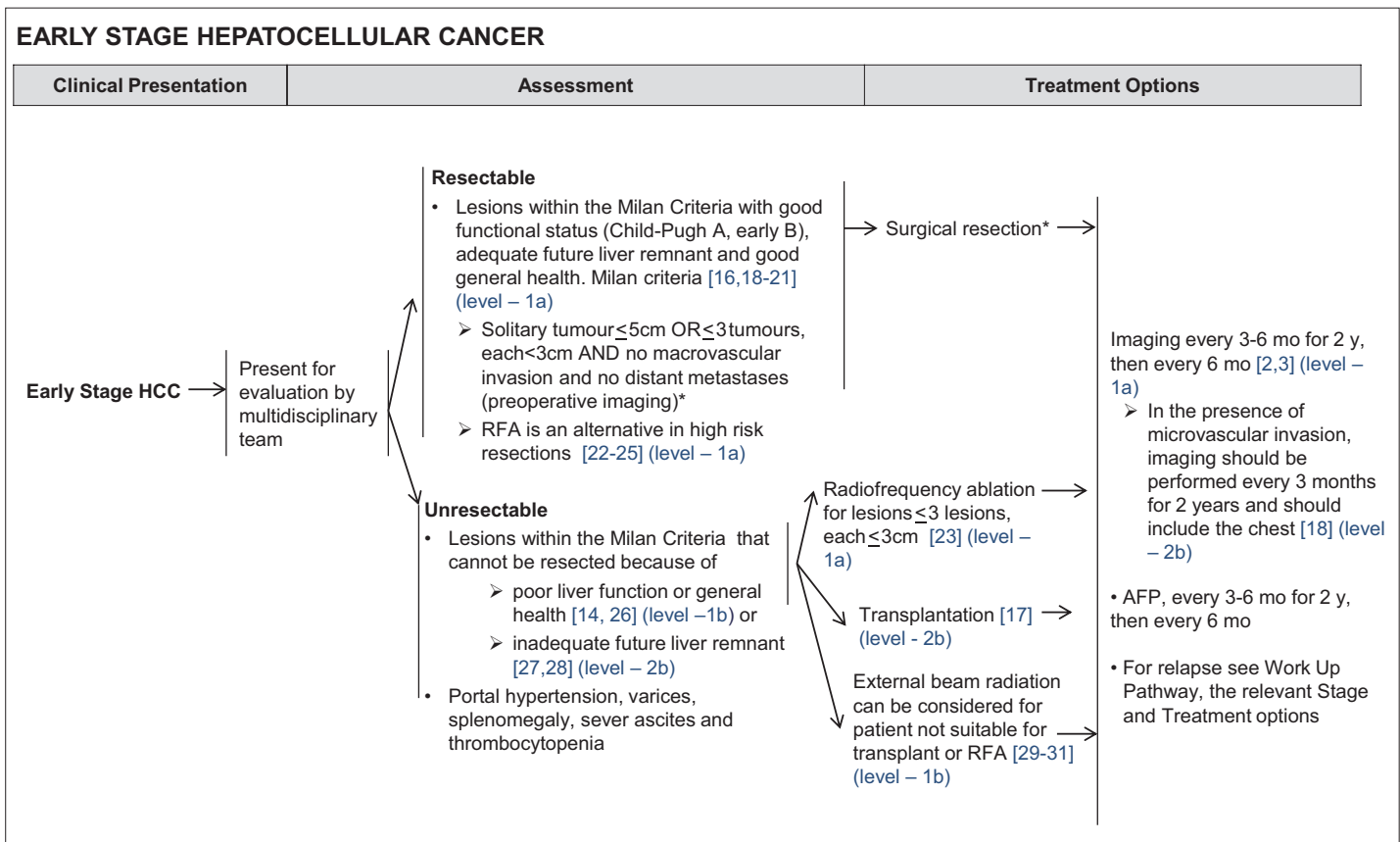

Fig. 3. NCCS Consensus Guidelines for HCC: Treatment for Early Stage HCC.

\section{Locally Advanced HCC}

Patients with locally advanced HCC lie outside the Milan Criteria, but do not have any distant metastases. However, they may or may not have vascular invasion. If these patients have poor liver function, treatment options are limited to palliative treatment, or if suitable, enrolment in clinical trials. However, if these patients have good liver function, locoregional therapy is feasible. Appropriate treatment for patients with good liver function include surgical resection for carefully selected cases after multidisciplinary board evaluation, enrolment into clinical trials, or transplantation for HCC within the University of California, San Francisco (UCSF) expanded criteria. Assessment for transplantation is made by a multidisciplinary team, with the expanded UCSF criteria covering single tumours $<6.5 \mathrm{~cm}$ in diameter or 2-3 tumours $<4.5 \mathrm{~cm}$ in diameter at the most, and in either case, total tumour diameter must be $<8 \mathrm{~cm}$ in diameter $[45,46]$ (Level $2 \mathrm{~b}$ Therapy) (fig. 4). Resection is a primary consideration for solitary lesions beyond the Milan criteria but with good liver function and adequate future liver remnant. Where living donor liver transplant is an option, transplantation beyond the UCSF criteria may be considered.

Locoregional therapy for locally advanced HCC with vascular invasion includes SIRT [31, 32, 47] (Level 2b Therapy) (fig. 4) and EBRT (alone, or as part of combined modality therapy) [48, 49] (Level 2a Therapy) (fig. 4).

In the absence of vascular invasion, in addition to SIRT [31, 32, 47] (Level 2b Therapy) (fig. 4) and EBRT, TACE remains as a viable alternative [50,51] (Level 1b Therapy) (fig. 4).

Sorafenib may also be used for any patient with locally advanced HCC, regardless of whether vascular invasion is absent [31, 32, 50, 51] (Level 1b Therapy) (fig. 4) or present [35, 36, 52, 53] (Level 1b Therapy) (fig. 4).

\section{Metastatic HCC}

In patients with imaging evidence of metastatic HCC, a biopsy can be considered to confirm the presence of metastatic disease. Palliative radiotherapy is appropriate for patients 


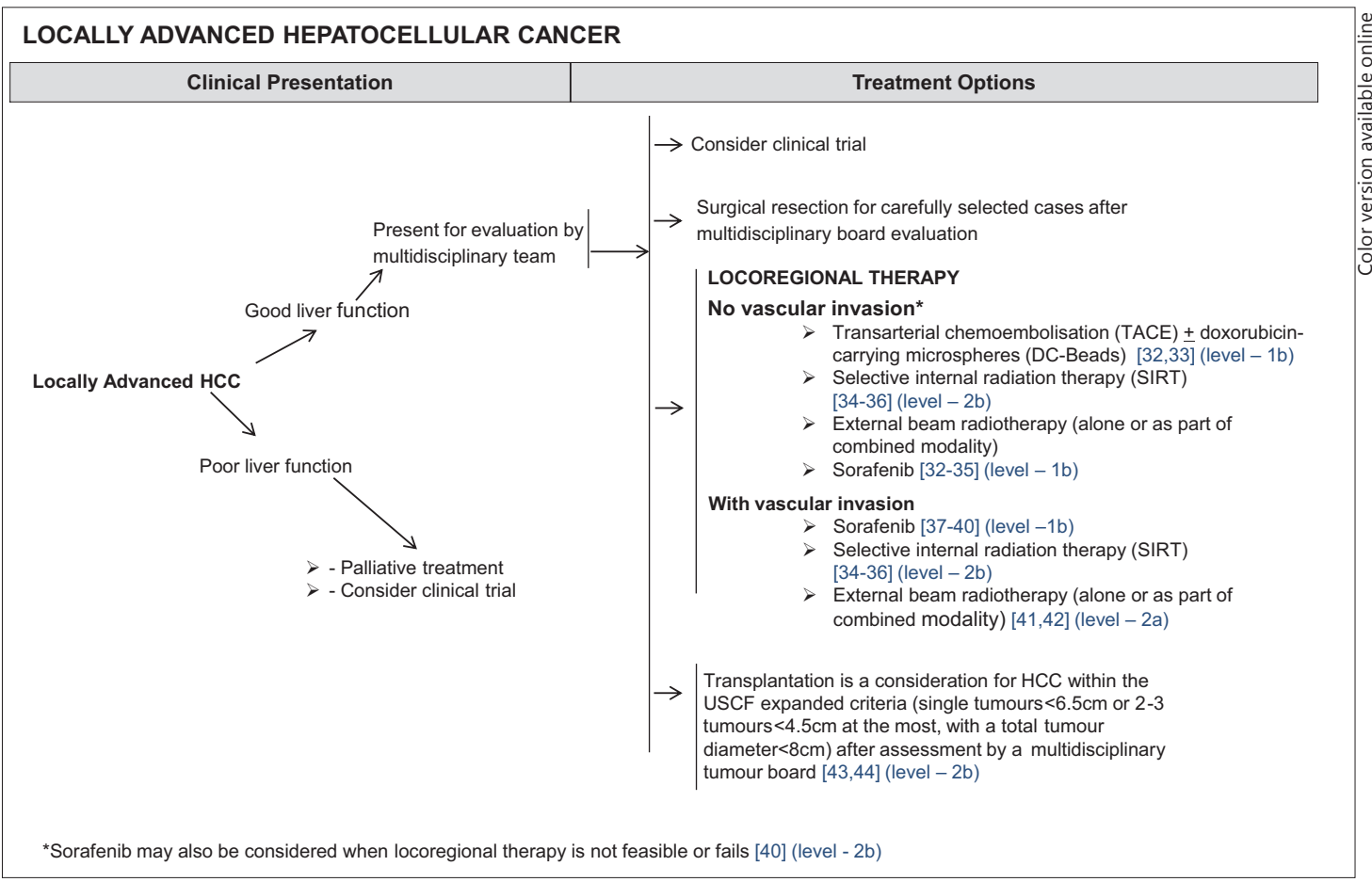

Fig. 4. NCCS Consensus Guidelines for HCC: Treatment for Locally Advanced HCC. DC-Beads=doxorubicincarrying microspheres; RT=radiotherapy; UCSF=University of California, San Francisco.

\begin{tabular}{|c|c|c|c|}
\hline \multicolumn{4}{|c|}{ METATASTIC HEPATOCELLULAR CANCER } \\
\hline & linical Presentation & & Treatment Options \\
\hline Metatastic $\mathrm{HCC} \rightarrow$ & \begin{tabular}{l|l} 
Present for & \\
evaluation by \\
multidisciplinary \\
team at TBM
\end{tabular} & $\begin{array}{l}\text { Consider biopsy to } \\
\text { confirm metastatic } \\
\text { disease }\end{array}$ & $\begin{array}{l}\text { Patients with good liver function (Child-Pugh A or B) } \\
\text { - Systemic therapy } \\
\text { > Sorafenib (Child-Pugh Class A or B) }[37,45] \text { (level - 1b) } \\
\text { - Consideration for clinical trial } \\
\text { - Palliative radiotherapy as appropriate } \\
\text { Patients with poor liver function } \\
\text { - Best supportive care } \\
\text { - Consideration for clinical trial } \\
\text { - Palliative radiotherapy as appropriate ) [29] (level - 2a) }\end{array}$ \\
\hline
\end{tabular}

Fig. 5. NCCS Consensus Guidelines for HCC: Treatment for Metastatic HCC. TBM=tumour board meetings.

with poor liver function [41] (Level 2a Therapy) (fig. 5). Those with good liver function are treated with sorafenib [36, 54] (Level 1b Therapy) (fig. 5). For metastatic HCC with a heavy tumour burden in the liver and good liver reserve, locoregional therapy such as TACE or SIRT can be considered after multidisciplinary assessment. Patients with metastatic disease may be enrolled in clinical trials. 


\section{Conclusion}

These guidelines have been successfully implemented in the CLCC since their publication online on $26^{\text {th }}$ September 2014. The guidelines allow outcomes of treatment to be compared to international data. Moving forward, the guidelines will be reviewed periodically to ensure that they remain based on the latest available scientific evidence; the extent of the CLCC's compliance with these guidelines will also be reviewed by way of clinical audit.

\section{Acknowledgements}

The authors would like to thank Mr. Goh Zhaohan LLB (Hons) for his editorial assistance.

\section{Disclosure Statement}

The authors declare that no conflict of interest exists.

\section{References}

1 Theise ND, Chen C, Kew MK: Liver Cancer; in Stewart BW, Wild CP (eds): World Cancer Report 2014. International Agency for Research on Cancer. Lyon, International Agency for Research on Cancer, 2014, pp578.

2 Lee HP, Chew L, Chow KY, Khaing TT, Loy EY, Ho W: Singapore Cancer Registry Interim Annual Registry Report: Trends in Cancer Incidence in Singapore 2009-2013. Health Promot Board Singap 20142014.

3 Burak KW, Kneteman NM: An evidence-based multidisciplinary approach to the management of hepatocellular carcinoma (HCC): the Alberta HCC algorithm. Can J Gastroenterol 2010;24:643-650.

4 Kudo M, Han KH, Kokudo N, Cheng AL, Choi BI, Furuse J, Izumi N, Park JW, Poon RT, Sakamoto M: Liver Cancer Working Group report. Jpn J Clin Oncol 2010;40(Suppl 1):i19-i27.

5 Dhanasekaran R, Limaye A, Cabrera R: Hepatocellular carcinoma: current trends in worldwide epidemiology, risk factors, diagnosis, and therapeutics. Hepat Med. 2012;4:19-37.

6 Gomaa AI, Khan SA, Toledano MB, Waked I, Taylor-Robinson SD: Hepatocellular carcinoma: epidemiology, risk factors and pathogenesis. World J Gastroenterol 2008;14:4300-4308.

7 Bruix J, Sherman M, American Association for the Study of Liver Diseases: Management of hepatocellular carcinoma: an update. Hepatology 2011;53:1020-1022.

8 Bruix J, Sherman M, Llovet JM, Beaugrand M, Lencioni R, Burroughs AK, Christensen E, Pagliaro L, Colombo M, Rodés J, EASL Panel of Experts on HCC European Association for the Study of the Liver: Clinical management of hepatocellular carcinoma. Conclusions of the Barcelona-2000 EASL conference. J Hepatol 2001;35:421-430.

9 Omata M, Lesmana LA, Tateishi R, Chen PJ, Lin SM, Yoshida H, Kudo M, Lee JM, Choi BI, Poon RT, Shiina S, Cheng AL, Jia JD, Obi S, Han KH, Jafri W, Chow P, Lim SG, Chawla YK, Budihusodo U, Gani RA, Lesmana CR, Putranto TA, Liaw YF, Sarin SK: Asian Pacific Association for the Study of the Liver consensus recommendations on hepatocellular carcinoma. Hepatol Int 2010;4:439-474.

10 Kudo M, Izumi N, Kokudo N, Matsui O, Sakamoto M, Nakashima O, Kojiro M, Makuuchi M, HCC Expert Panel of Japan Society of Hepatology: Management of hepatocellular carcinoma in Japan: Consensus-Based Clinical Practice Guidelines proposed by the Japan Society of Hepatology (JSH) 2010 updated version. Dig Dis 2011;29:339-364.

11 Korean Liver Cancer Study Group (KLCSG), National Cancer Center, Korea (NCC): 2014 KLCSG-NCC Korea Practice Guideline for the Management of Hepatocellular Carcinoma.Gut and liver 2015;9:267-317.

12 Poon RT, Cheung TT, Kwok PC, Lee AS, Li TW, Loke KL, Chan SL, Cheung MT, Lai TW, Cheung CC, Cheung FY, Loo CK, But YK, Hsu SJ, Yu SC, Yau T: Hong Kong consensus recommendations on the management of hepatocellular carcinoma. Liver Cancer 2015;4:51-69.

13 Benson AB 3rd, Abrams TA, Ben-Josef E, Bloomston PM, Botha JF, Clary BM, Covey A, Curley SA, D'Angelica MI, Davila R, Ensminger WD, Gibbs JF, Laheru D, Malafa MP, Marrero J, Meranze SG, Mulvihill SJ, Park JO, Posey JA, Sachdev J, Salem R, Sigurdson ER, Sofocleous C, Vauthey JN, Venook AP, Goff LW, Yen Y, Zhu AX: NCCN clinical practice guidelines in oncology: hepatobiliary cancers. J Natl Compr Canc Netw 2009;7:350-391. 
14 National Cancer Centre Singapore Comprehensive Liver Cancer Clinic Guidelines: In. 2014. http://www. nccs.com.sg/PatientCare/ComprehensiveLiverCancerClinic/Documents/CLCC\%20guideline\%20\%20 Final\%20Ver\%20to\%20upload\%20PDF\%2026092014.pdf. Accessed 8 June 2015.

15 Howick J, Chalmers I, Glasziou P, Greenhalgh T, Heneghan C, Liberati A, Moschetti I, Phillips B, Thornton H, Goddard O, Hodgkinson M: OCEBM Levels of Evidence Working Group: The Oxford 2011 Levels of Evidence. 2011.

16 Lee MH, Kim SH, Park MJ, Park CK, Rhim H: Gadoxetic acid-enhanced hepatobiliary phase MRI and high-bvalue diffusion-weighted imaging to distinguish well-differentiated hepatocellular carcinomas from benign nodules in patients with chronic liver disease. AJR Am J Roentgenol 2011;197:W868-75.

17 Zech CJ, Bartolozzi C, Bioulac-Sage P, Chow PK, Forner A, Grazioli L, Huppertz A, Laumonier H, Min Lee J, Murakami T, Ricke J, Sirlin CB: Consensus report of the Fifth International Forum for Liver MRI. AJR Am J Roentgenol 2013;201:97-107.

18 Rode A, Bancel B, Douek P, Chevallier M, Vilgrain V, Picaud G, Henry L, Berger F, Bizollon T, Gaudin JL, Ducerf C: Small nodule detection in cirrhotic livers: evaluation with US, spiral CT, and MRI and correlation with pathologic examination of explanted liver. J Comput Assist Tomogr 2001;25:327-336.

19 Sangiovanni A, Manini MA, Iavarone M, Romeo R, Forzenigo LV, Fraquelli M, Massironi S, Della Corte C, Ronchi G, Rumi MG, Biondetti P, Colombo M: The diagnostic and economic impact of contrast imaging techniques in the diagnosis of small hepatocellular carcinoma in cirrhosis. Gut 2010;59:638-644.

20 Forner A, Vilana R, Ayuso C, Bianchi L, Solé M, Ayuso JR, Boix L, Sala M, Varela M, Llovet JM, Brú C, Bruix J: Diagnosis of hepatic nodules $20 \mathrm{~mm}$ or smaller in cirrhosis: Prospective validation of the noninvasive diagnostic criteria for hepatocellular carcinoma. Hepatology 2008;47:97-104.

21 Ryder SD, British Society of Gastroenterology: Guidelines for the diagnosis and treatment of hepatocellular carcinoma (HCC) in adults. Gut 2003;52(Suppl 3):iii1-iii8.

22 Sherman M, Peltekian KM, Lee C: Screening for hepatocellular carcinoma in chronic carriers of hepatitis B virus: incidence and prevalence of hepatocellular carcinoma in a North American urban population. Hepatology 1995;22:432-438.

23 Clavien PA, Petrowsky H, DeOliveira ML, Graf R: Strategies for safer liver surgery and partial liver transplantation. N Engl J Med 2007;356:1545-1559.

24 Lau H, Man K, Fan ST, Yu WC, Lo CM, Wong J: Evaluation of preoperative hepatic function in patients with hepatocellular carcinoma undergoing hepatectomy. Br J Surg 1997;84:1255-1259.

25 Llovet JM, Burroughs A, Bruix J: Hepatocellular carcinoma. Lancet 2003;362:1907-1917.

26 Mazzaferro V, Regalia E, Doci R, Andreola S, Pulvirenti A, Bozzetti F, Montalto F, Ammatuna M, Morabito A, Gennari L: Liver transplantation for the treatment of small hepatocellular carcinomas in patients with cirrhosis. N Engl J Med 1996;334:693-699.

27 Lim KC, Chow PK, Allen JC, Siddiqui FJ, Chan ES, Tan SB: Systematic review of outcomes of liver resection for early hepatocellular carcinoma within the Milan criteria. Br J Surg 2012;99:1622-1629.

28 Pelletier SJ, Fu S, Thyagarajan V, Romero-Marrero C, Batheja MJ, Punch JD, Magee JC, Lok AS, Fontana RJ, Marrero JA: An intention-to-treat analysis of liver transplantation for hepatocellular carcinoma using organ procurement transplant network data. Liver Transpl 2009;15:859-868.

29 Adam R, Karam V, Delvart V, O'Grady J, Mirza D, Klempnauer J, Castaing D, Neuhaus P, Jamieson N, Salizzoni M, Pollard S, Lerut J, Paul A, Garcia-Valdecasas JC, Rodríguez FS, Burroughs A, All contributing centers (www.eltr.org) European Liver and Intestine Transplant Association (ELITA): Evolution of indications and results of liver transplantation in Europe. A report from the European Liver Transplant Registry (ELTR). J Hepatol 2012;57:675-688.

30 Li L, Zhang J, Liu X, Li X, Jiao B, Kang T: Clinical outcomes of radiofrequency ablation and surgical resection for small hepatocellular carcinoma: a meta-analysis. J Gastroenterol Hepatol 2012;27:51-58.

31 Sangro B, Carpanese L, Cianni R, Golfieri R, Gasparini D, Ezziddin S, Paprottka PM, Fiore F, Van Buskirk M, Bilbao JI, Ettorre GM, Salvatori R, Giampalma E, Geatti O, Wilhelm K, Hoffmann RT, Izzo F, Iñarrairaegui M, Maini CL, Urigo C, Cappelli A, Vit A, Ahmadzadehfar H, Jakobs TF, Lastoria S, European Network on Radioembolization with Yttrium-90 Resin Microspheres (ENRY): Survival after yttrium-90 resin microsphere radioembolization of hepatocellular carcinoma across Barcelona clinic liver cancer stages: a European evaluation. Hepatology 2011;54:868-878.

32 Khor AY, Toh Y, Allen JC, Ng DC, Kao YH, Zhu G, Choo SP, Lo RH, Tay KH, Teo JY, Goh BK, Burgmans MC, Irani FG, Goh AS, Chow PK: Survival and pattern of tumor progression with yttrium-90 microsphere radioembolization in predominantly hepatitis B Asian patients with hepatocellular carcinoma. Hepatol Int 2014;8:395-404.

33 Bolondi L, Burroughs A, Dufour JF, Galle PR, Mazzaferro V, Piscaglia F, Raoul JL, Sangro B: Heterogeneity of patients with intermediate (BCLC B) Hepatocellular Carcinoma: proposal for a subclassification to facilitate treatment decisions. Semin Liver Dis 2012;32:348-359.

34 Salem R, Lewandowski RJ, Mulcahy MF, Riaz A, Ryu RK, Ibrahim S, Atassi B, Baker T, Gates V, Miller FH, Sato KT, Wang E, Gupta R, Benson AB, Newman SB, Omary RA, Abecassis M, Kulik L: Radioembolization for hepatocellular carcinoma using Yttrium-90 microspheres: a comprehensive report of long-term outcomes. Gastroenterology 2010;138:52-64.

35 Cheng AL, Kang YK, Chen Z, Tsao CJ, Qin S, Kim JS, Luo R, Feng J, Ye S, Yang TS, Xu J, Sun Y, Liang H, Liu J, Wang J, Tak WY, Pan H, Burock K, Zou J, Voliotis D, Guan Z: Efficacy and safety of sorafenib in patients in the Asia-Pacific region with advanced hepatocellular carcinoma: a phase III randomised, double-blind, placebo-controlled trial. Lancet Oncol 2009;10:25-34. 
36 Llovet JM, Ricci S, Mazzaferro V, Hilgard P, Gane E, Blanc JF, de Oliveira AC, Santoro A, Raoul JL, Forner A, Schwartz M, Porta C, Zeuzem S, Bolondi L, Greten TF, Galle PR, Seitz JF, Borbath I, Häussinger D, Giannaris T, Shan M, Moscovici M, Voliotis D, Bruix J, SHARP Investigators Study Group: Sorafenib in advanced hepatocellular carcinoma. N Engl J Med 2008;359:378-390.

37 Lim KC, Chow PK, Allen JC, Chia GS, Lim M, Cheow PC, Chung AY, Ooi LL, Tan SB: Microvascular invasion is a better predictor of tumor recurrence and overall survival following surgical resection for hepatocellular carcinoma compared to the Milan criteria. Ann Surg 2011;254:108-113.

38 Lim KC, Wang VW, Siddiqui FJ, Shi L, Chan ES, Oh HC, Tan SB, Chow PK: Cost-effectiveness analysis of liver resection versus transplantation for early hepatocellular carcinoma within the Milan criteria. Hepatology 2015;61:227-237.

39 Llovet JM, Fuster J, Bruix J: Intention-to-treat analysis of surgical treatment for early hepatocellular carcinoma: resection versus transplantation. Hepatology 1999;30:1434-1440.

40 Tiong L, Maddern GJ: Systematic review and meta-analysis of survival and disease recurrence after radiofrequency ablation for hepatocellular carcinoma. Br J Surg 2011;98:1210-1224.

41 Kwon JH, Bae SH, Kim JY, Choi BO, Jang HS, Jang JW, Choi JY, Yoon SK, Chung KW: Long-term effect of stereotactic body radiation therapy for primary hepatocellular carcinoma ineligible for local ablation therapy or surgical resection. Stereotactic radiotherapy for liver cancer. BMC Cancer 2010;10:475.

42 Hawkins MA, Dawson LA: Radiation therapy for hepatocellular carcinoma: from palliation to cure. Cancer 2006;106:1653-1663.

43 Andolino DL, Johnson CS, Maluccio M, Kwo P, Tector AJ, Zook J, Johnstone PA, Cardenes HR: Stereotactic body radiotherapy for primary hepatocellular carcinoma. Int J Radiat Oncol Biol Phys 2011;81:e447e453.

44 Zhang BH, Yang BH, Tang ZY: Randomized controlled trial of screening for hepatocellular carcinoma. J Cancer Res Clin Oncol 2004;130:417-422.

45 Yao FY, Ferrell L, Bass NM, Watson JJ, Bacchetti P, Venook A, Ascher NL, Roberts JP: Liver transplantation for hepatocellular carcinoma: expansion of the tumor size limits does not adversely impact survival. Hepatology 2001;33:1394-1403.

46 Duffy JP, Vardanian A, Benjamin E, Watson M, Farmer DG, Ghobrial RM, Lipshutz G, Yersiz H, Lu DS, Lassman C, Tong MJ, Hiatt JR, Busuttil RW: Liver transplantation criteria for hepatocellular carcinoma should be expanded: a 22-year experience with 467 patients at UCLA. Ann Surg 2007;246:502-509, discussion 509-511.

47 Kulik LM, Carr BI, Mulcahy MF, Lewandowski RJ, Atassi B, Ryu RK, Sato KT, Benson A 3rd, Nemcek AA Jr, Gates VL, Abecassis M, Omary RA, Salem R: Safety and efficacy of 90Y radiotherapy for hepatocellular carcinoma with and without portal vein thrombosis. Hepatology 2008;47:71-81.

48 Kang JK, Kim MS, Cho CK, Yang KM, Yoo HJ, Kim JH, Bae SH, Jung H, Kim KB, Lee DH, Han CJ, Kim J, Park SC, Kim YH: Stereotactic body radiation therapy for inoperable hepatocellular carcinoma as a local salvage treatment after incomplete transarterial chemoembolization. Cancer 2012;118:5424-5431.

49 Hoffe SE, Finkelstein SE, Russell MS, Shridhar R: Nonsurgical options for hepatocellular carcinoma: evolving role of external beam radiotherapy. Cancer Contr 2010;17:100-110.

50 Golfieri R, Giampalma E, Renzulli M, Cioni R, Bargellini I, Bartolozzi C, Breatta AD, Gandini G, Nani R, Gasparini D, Cucchetti A, Bolondi L, Trevisani F, PRECISION ITALIA STUDY GROUP: Randomised controlled trial of doxorubicin-eluting beads vs conventional chemoembolisation for hepatocellular carcinoma. $\mathrm{Br}$ J Cancer 2014;111:255-264.

51 Lammer J, Malagari K, Vogl T, Pilleul F, Denys A, Watkinson A, Pitton M, Sergent G, Pfammatter T, Terraz S, Benhamou Y, Avajon Y, Gruenberger T, Pomoni M, Langenberger H, Schuchmann M, Dumortier J, Mueller C, Chevallier P, Lencioni R, PRECISION V Investigators: Prospective randomized study of doxorubicin-eluting-bead embolization in the treatment of hepatocellular carcinoma: results of the PRECISION V study. Cardiovasc Intervent Radiol 2010;33:41-52.

52 Raoul JL, Bruix J, Greten TF, Sherman M, Mazzaferro V, Hilgard P, Scherubl H, Scheulen ME, Germanidis G, Dominguez S, Ricci S, Nadel A, Moscovici M, Voliotis D, Llovet JM: Relationship between baseline hepatic status and outcome, and effect of sorafenib on liver function: SHARP trial subanalyses. J Hepatol 2012;56:1080-1088.

53 Chow PK, Poon DY, Khin MW, Singh H, Han HS, Goh AS, Choo SP, Lai HK, Lo RH, Tay KH, Lim TG, Gandhi M, Tan SB, Soo KC, Asia-Pacific Hepatocellular Carcinoma Trials Group: Multicenter phase II study of sequential radioembolization-sorafenib therapy for inoperable hepatocellular carcinoma. PLoS ONE 2014;9:e90909.

54 Miller AA, Murry DJ, Owzar K, Hollis DR, Kennedy EB, Abou-Alfa G, Desai A, Hwang J, Villalona-Calero MA, Dees EC, Lewis LD, Fakih MG, Edelman MJ, Millard F, Frank RC, Hohl RJ, Ratain MJ: Phase I and pharmacokinetic study of sorafenib in patients with hepatic or renal dysfunction: CALGB 60301. J Clin Oncol 2009;27:1800-1805. 